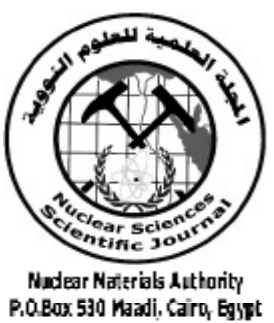

ISSN 2314-5609

Nuclear Sciences Scientific Journal

$6,209-223$

2017

http://www.ssnma.com

\title{
RADIATION HAZARDS INDICES, RADON EXHALATION RATES AND RADON DIFFUSION LENGTH FOR SOME SOIL SAMPLES, WADI NASEIB AREA, SINAI, EGYPT
}

\author{
SAYED F. HASSAN ; MOHAMED S. EL NAGDY ${ }^{1}$; AHMED S. SHATA \\ and KORANY A. KORANY ${ }^{1}$ \\ Nuclear Material Authority (NMA), P.O .Box:530 El Maadi, Cairo, Egypt; ' ${ }^{1}$ physics Dept., Fac. Sci., \\ Helwan Univ., Cairo, Egypt
}

\begin{abstract}
The radiological effects from 21 soil samples collected from Wadi Nasib area of approximately 40 $\mathrm{Km}^{2}$, Sinai, Egypt, were measured using gamma spectrometer. CR-39 plastic track detector was used for radon exhalation rate measurements employing (closed can technique). The uranium concentrations were also measured for these samples as well as radium equivalent concentrations. The obtained results show: The radon exhalation rates were found to vary from 1.48 to $63.36 \mathrm{~Bq} \mathrm{~m}^{-2} \mathrm{~h}^{-1}$. Uranium concentration varies from 1 to $89 \mathrm{ppm}$, whereas Radium concentration in soil samples has been found to vary from 2 to $114 \mathrm{ppm}$. The radon levels at the depths of $1 \mathrm{~m}$ are nearly twice the levels at $0.5 \mathrm{~m}$ in the experimented area. The rate of radon diffusion is found to depend mainly upon medium porosity. The annual effective dose measured for this area exceeds the permissible values, recommendations and precaution should be undertaken during any exploration processes in this area
\end{abstract}

\section{INTRODUCTION}

Naturally Radon $(\mathrm{Rn})$ is found as a product of three radioactive decay series (Uranium series-Thorium series-Actinium series). During the decay of Uranium series it produces Radium ${ }^{226} \mathrm{Ra}$ isotope which decays to radon ${ }^{222} \mathrm{Rn}$ with a half-life of (3.82 days). Also Thoron ${ }^{220} \mathrm{Rn}$ is the result of the decay of Thorium in the Thorium series, it has a halflife time of (54.4) seconds. Finally Actinon ${ }^{219} \mathrm{Ra}$ is the result of the decay of Actinium in the Actinium series, it has a halflife time of (3.92) seconds. All these isotopes decay by alpha emission unless Actinon is also a gamma emitter. The prominent role of radon among all natural radioelements is due to the fact that it basically is an inert gas (Anastasiou et al., 2003). Once formed from one of the natural radioactive series in the Earth's crust it is free to diffuse into soil air and then to the atmosphere by pressure driven flow or further diffusion (Wilkening , 1990, Abumurad et al., 1997). Radon is a colorless and ouderless gas with a density of $9.73 \mathrm{~g} / 1$ under standard conditions. Atoms of ${ }^{222} \mathrm{Rn}$ may be released from a planar rock surface by any or combination of the following mechanisms (Hassan ,1999) $i$ )Recoil off the surface if the decay of ${ }^{226} \mathrm{Ra}$ atoms is within the alpha recoil range from the surface.ii)Diffusion through the rock lattice from production sites below the rock surface. iii)Diffusion along the crystal defects, grain boundaries or microfractures from greater depths below the rock surface.

Exhalations designate the escape of radon from a material to atmosphere. This process 
can occur by molecular diffusion or by convection (Schery et al., 1988). Besides the moisture content, the exhalation of radon is positively correlated with the temperature and wind speed and negatively with pressure, so that these factors must be considered in the determination of exhalation rates in environmental measurements (Gomez et al., 1999)

Aim of the present work: This work aims to estimate the radiation hazard indices in soils samples from west eastern Sinai bensuila and assessing the annual effective dose equivalents from the measured terrestrial radiation in the geographic area of study, as well as radon exhalation measurements, radon diffusion coefficients and diffusion lengths through soil.

\section{EXPERIMENTAL METHODS}

\section{Geological Setting}

Wadi Nasieb area is a part of southwestern Sinai, Egypt and is occupied by basement rocks of Late Proterozoic age, which unconformably overlain by Paleozoic rocks. The area under investigation is located about 40 $\mathrm{km}$ east of $\mathrm{Abu}$ Zeneima town in the southwestern part of Sinai Peninsula. It is bounded by Lat. $29^{\circ} 10^{\prime} 30^{\prime \prime}$ and $29^{\circ} 05^{\prime} \mathrm{N}$ and Long. $33^{\circ} 22^{\prime}$ and $33^{\circ} 25^{\prime} \mathrm{E}$ and it is covered by different rocks of Precambrian and Paleozoic ages (El Rakaiby, El Aassy , 1990). Twenty one, soil samples were collected from 21 stations covering different lithologies of the area under investigation the separation distance between each two stations is nearly ranged from 150 to $200 \mathrm{~m}$,

\section{Radiation Hazards Indices Factors}

The rock samples were crushed mechanically, dried and then ground to grain size of about -100 mish. The powder rock samples were transferred to polyethylene circular containers of $10 \mathrm{~cm}$ diameter and $3 \mathrm{~cm}$ height. Every sample was then pressed manually in its container till it was completely filled and then it is tightly closed and stored sealed for about one month to reach the state of equilibrium between radium and its daughters. A high efficiency multi-channel analyzer of $\gamma$ ray spectrometry $\mathrm{NaI}(\mathrm{Tl})$ detector was used for measuring the concentration of ${ }^{238} \mathrm{U},{ }^{232} \mathrm{Th}$, ${ }^{226} \mathrm{Ra}$ and ${ }^{40} \mathrm{~K}$ for the selected samples. The values of eU, eTh and eRa, in ppm, as well as $\mathrm{K}$, in $\%$, were converted to the activity concentration, in $\mathrm{Bq} \mathrm{kg}^{-1}$ using the conversion factors given by (UNSCEAR, 2000). Table (1) shows the values for the conversion factors used. The analysis was carried out in the Egyptian Nuclear Materials Authority laboratories, the expected environmental impacts of the radionuclides are investigated in terms of exposure and dose rates, external and internal hazard indices, and a radioactivity level index.

\section{Exposure rate and dose rate}

The exposure rate $(\mu \mathrm{R} / \mathrm{h})$ is related to the measured radio-nuclide concentration as (Beck, et al. (1972).

The exposure rate $(\mu \mathrm{R} / \mathrm{h})=0.653 \mathrm{U}(\mathrm{ppm})+0.287 \mathrm{Th}(\mathrm{ppm})+1.505 \mathrm{~K} \%$

The same method also can be used to calculate the absorbed dose rate (nGy/h) from the following equation (Beck, et al. (1972).

The dose rate $(\mathrm{nGy} / \mathrm{h})=5.476 \mathrm{U}(\mathrm{ppm})+2.494 \mathrm{Th}(\mathrm{ppm})+13.078 \mathrm{~K} \%$

\section{Effective dose rate}

The estimation of the annual effective dose, the conversion factor from absorbed dose in air to effective dose and the outdoor occupancy factor must be taken into in unit of $\mathrm{mSv}$ per year, is calculated from the following equation (Grasety R. L.,1978).

Table 1: Conversion of radioelement concentration to specific activity (UNSCEAR,2000)

\begin{tabular}{lrr}
\hline Radio-element & Chemical concentration & Specific activity \\
\hline${ }^{40} \mathrm{~K}$ & $1 \% \mathrm{~K}$ in rock & $313.0 \mathrm{~Bq} / \mathrm{Kg}$ \\
${ }^{238} \mathrm{U}$ and ${ }^{226} \mathrm{Ra}$ & $\mathrm{I} \mathrm{ppm} \mathrm{U}$ in rock & $12.35 \mathrm{~Bq} / \mathrm{Kg}$ \\
${ }^{232} \mathrm{Th}$ & I ppm Th in rock & $4.060 \mathrm{~Bq} / \mathrm{Kg}$
\end{tabular}


$\mathrm{mSvy}^{-1}=\left(\mathrm{n} \mathrm{GY} \mathrm{h}^{-1}\right) \times 24 \mathrm{~h} \times 365.24 \mathrm{~d} \times 0.2 \times 0.7 \mathrm{~Sv} \mathrm{~Gy}^{-1} \times 10^{-6}$

Where, $\mathrm{mSvy}^{-1}$ is the effective dose rate, $\left(\mathrm{n} \mathrm{Gy} \mathrm{h}^{-1}\right)$ is the dose rate and $\mathrm{Sv} \mathrm{Gy}^{-1}$ is the conversion coefficient.

The international commission of radiological protection (ICRP, 1979) recommended that no individual should receive more than $50 \mathrm{mSvy}^{-1}$ from all natural and artificial radiation sources. The recent recommendation of (IAEA, 1996) indicated that the permissible level of dose rates reaching up to $5 \mathrm{mSv} \mathrm{y}^{-1}$ for public members and up to $20 \mathrm{mSv} \mathrm{y}^{-1}$ for the occupational members.

\section{Radium equivalent concentration $\left(R a_{e q}\right)$ activity}

The combined specific activity of ${ }^{226} \mathrm{Ra}$, ${ }^{232} \mathrm{Th}$, and ${ }^{40} \mathrm{~K}$ develop a numerical indicator of an external dose to public (Beretka ,and Mathaw ,1985). Suggested the following equation to calculate radium equivalent and stated the value of $379 \mathrm{~Bq} / \mathrm{kg}$ as the maximum allowed dose for public.

$\mathrm{Ra}_{\mathrm{eq}}=\mathrm{A}_{\mathrm{Ra}}+1.43 \mathrm{~A}_{\mathrm{Th}}+0.077 \mathrm{~A}_{\mathrm{K}} \leq 370$

Where, $A_{R a}, A_{T h}$ and $A_{K}$ are the specific activities of $\mathrm{Ra}, \mathrm{Th}$ and $\mathrm{K}$, in $\mathrm{Bq} / \mathrm{kg}$, respectively.

\section{External hazard $\left(\mathrm{H}_{\mathrm{ex}}\right)$}

The external hazard index $\left(\mathrm{H}_{\mathrm{ex}}\right)$ was used to measure the external hazard due to the emitted gamma radiation. It was calculated by the equation from Krieger, 1981.

$H_{\mathrm{ex}}=\mathrm{A}_{\mathrm{Ra}} / 370+\mathrm{A}_{\mathrm{Th}} / 259+\mathrm{A}_{\mathrm{K}} / 4810 \leq 1$

Where $\mathrm{H}_{\mathrm{ex}}$; is the external hazrd index.

\section{Internal hazard $\left(\mathrm{H}_{\mathrm{in}}\right)$}

In addition to external hazard index, radon and its short-lived products are also hazardous to the respiratory organs. So, the internal radon and its daughter products are quantified by the internal hazard index Hin whish is given by (Krieger, 1981):

$\mathrm{H}_{\text {in }}=\mathrm{A}_{\mathrm{Ra}} / 185+\mathrm{A}_{\mathrm{Th}} / 259+\mathrm{A}_{\mathrm{K}} / 4810 \leq 1$

\section{Level index (I-gamma)}

The estimation of radiation risk level (I- $\gamma$ ) which controlling by gamma ray associated with radio-nuclides in specific materials. It is calculated from the following equation (Grasety , 1978).

$(\mathrm{I}-\gamma)=\mathrm{S}_{\mathrm{Ra}} / 150+\mathrm{S}_{\mathrm{Th}} / 100+\mathrm{S}_{\mathrm{K} \%} / 1500 \leq 1$

\section{Measurements of Radon Exhalation Rate}

In this case 'can technique' (Khan et al., 1992) was used. A CR-39 plastic track detector $(1 \mathrm{x} 1 \mathrm{~cm})$ was fixed on the top inside of a cylindrical plastic can of $11 \mathrm{~cm}$ height and 8 cm diameter, Fig.(1).

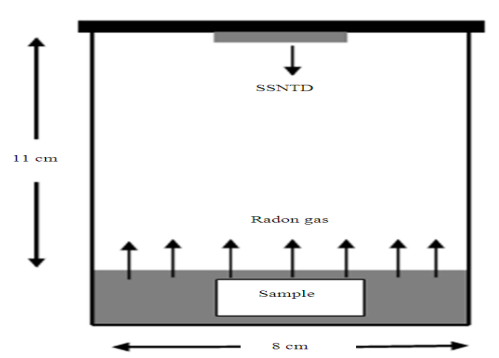

Fig. 1: Experimental set-up for the measurement of radon exhalation (AbdElzaher M.,2012)

Equal amounts of each sieved (200 mm grains size) samples (100-200 gm) was placed at the base of each can. The cans were sealed for 90 days. The lower sensitive part of the detector was exposed freely to the emergent radon from the samples in the can so that it could record a-particles resulting from the decay of radon in the remaining volume of the can and from Po-218 and Po-214 deposited on the inner walls of the can. Radon and its daughters reach equilibrium in about $4 \mathrm{~h}$ and hence the activity of emergent radon can be obtained from the geometry of the can and the time of exposure. 
After exposure time, the detectors were etched in $6.25 \mathrm{~N} \mathrm{NaOH}$ at $70 \pm 1^{\circ} \mathrm{C}$ for 8 hour in a constant temperature water bath to reveal the tracks. The resulting $\alpha$-tracks were counted using an optical microscope at a magnification of 400X. The activity was calculated from the track density in the etched detectors using the calibration factor of $0.2217 \pm 0.035$ $\left(\mathrm{T} . \mathrm{cm}^{-2} \cdot \mathrm{d}-1 / \mathrm{Bq} \cdot \mathrm{m}^{-3}\right)$ obtained from the earlier calibration experiment (Said et al., 2009). The exhalation rate of radon is obtained from the expression (Khan et al., 1992).

$$
E_{x}=\frac{C V \lambda}{A\left[T+1 / \lambda\left(e^{-\lambda t}-1\right)\right]}
$$

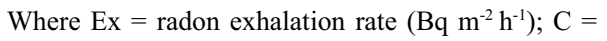
integrated radon exposure as measured by CR-39 detector $\left(\mathrm{Bq} \mathrm{m}^{-3}\right) ; \mathrm{V}=$ effective volume of the can $\left(\mathrm{m}^{3}\right) ; \lambda=$ decay constant for radon $\left(\mathrm{h}^{-1}\right) ; \mathrm{T}=$ exposure time $(\mathrm{h})$ and $\mathrm{A}=$ area of the can $\left(\mathrm{m}^{2}\right)$.

\section{Diffusion Coefficient and Diffusion Length}

The apparatus designed for the study of radon diffusion through different soil samples is shown on Fig.2, ((Korany et al., 2013). It consists of a hollow plastic cylinder of inner diameter $10 \mathrm{~cm}$ and length $100 \mathrm{~cm}$ deployed vertically in the earth. Each one was fitted with a four pieces of CR-39 plastic foil 500 $\mu \mathrm{m}$ thick and $(1 \mathrm{~cm} \times 1 \mathrm{~cm})$ in cross section. The detectors were fixed inside the pipe at different depths $25,50,75$ and $100 \mathrm{~cm}$ from its top side and covered from the top with metallic cover and from the bottom with filter paper. This configuration was used in order to maintain the same calibration conditions and to stop the thoron $\left({ }^{220} \mathrm{Rn}\right)$ from entering the tube, while allowing the radon gas to pass through the tube, for the selected measuring tube

Twenty one holes of $10 \mathrm{~cm}$ in diameter and $100 \mathrm{~cm}$ in depth were dug in each chosen point of measurement (Station). Every station was filled with a tube fixed with CR-39 detectors at different depths $(25,50,75$ and 100 $\mathrm{cm})$. The detectors were mounted in such a way that the sensitive surfaces facing the air

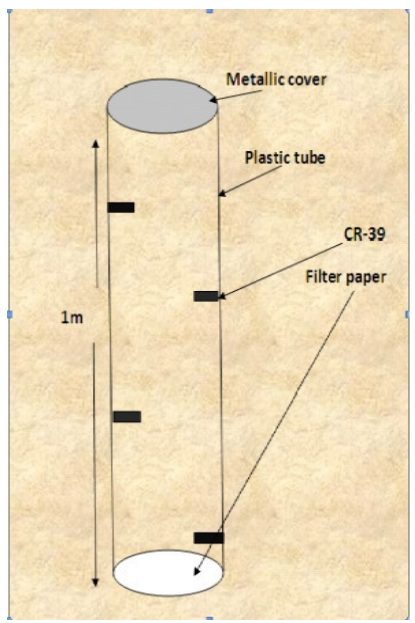

Fig.2: Schematic diagram showing the tube under the soil surface and the CR-39 at different depths

coming from the underground, taking due care that there was nothing to obstruct the detectors. Then each hole was refilled with soil. The $\alpha$-particles originating from radon and its progeny were registered as tracks in the detectors, if $\alpha$-particles from radon and its progeny have their energies in the range of about 1.7- 4.1 MeV (Durrani et al., 1988). Thus, the radon progeny, which plate out on the surface of the detectors will not be detected because their $\alpha$-particles are too energetic. The detectors were left in each station for approximately four weeks-long enough for the ${ }^{222} \mathrm{Rn}$ to reach equilibrium with its long-lived parent, radium and for a significant number of tracks resulting from its alpha decay to be registered on the CR-39 detector.

After exposure, the detectors were retrieved and etched, counted under the optimum conditions as mentioned above. The radon gas concentration ( $\mathrm{pCi} / \mathrm{l})$ was determined using the relation.

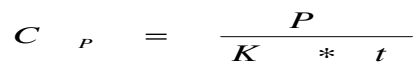

Where $(\mathrm{P})$ is the corrected track density (num- 
ber of tracks per $\left.\mathrm{cm}^{2}\right),[(\mathrm{K})=0.2217 \pm 0.035(\mathrm{Al}-$ Bataina et al. (2004)), is the calibration factor $\left\{\left(\right.\right.$ tracks. $\left.\left.\mathrm{cm}^{2} \cdot \mathrm{d}^{-1}\right) \cdot(\mathrm{pCi} / 1)^{-1}\right\}$ and $(\mathrm{t})$ is the total time of exposure. The radon concentrations in $\mathrm{K} \mathrm{Bq}^{-3}$ were calculated by using the relation:

$C\left(K B q / M^{3}\right)=0.037 * C_{P}(P C i / L)_{\text {coNC }}$

Radon diffusion and transport through different media is a complex process and is affected by several factors (Tanner, 1980). Radon diffusion through material media obeys the equation

$$
N=N_{0} \exp (-\sqrt{\lambda / D}) x
$$

Where $\mathrm{N}$ is the concentration of radon at any time $t$ at a distance $\mathrm{X}$ from source, N0 is the concentration of radon at source and $\lambda$ is the decay constant of radon.

If $\mathrm{N} 1$ and $\mathrm{N} 2$ are the radon concentrations at distances X1 and X2 from source respectively, then using Eq. (11) the diffusion coefficient $\mathrm{D}$ is given by

$D=\lambda\left[\left(X_{2}-X_{1}\right) / \ln \left(N_{1} / N_{2}\right)\right]^{2}$

This equation can be used to calculate radon diffusion coefficient through material medium.

The diffusion length can be calculated using the equation

$L=\sqrt{D / \lambda}$

Where: $\mathrm{D}$ is the radon diffusion coefficient and $\lambda$ is the decay constant of radon.

\section{Radiation Constants Determinations}

The relations between radon soil concentrations at different depths can be described by the function of (Tanner, 1964; Mogro-Campero et al., 1980; Kristiansson and Malmqvist, 1982) as:

$$
I(x)=A(1-\exp (-B x))
$$

Where, $\mathrm{I}(\mathrm{x})$ is the radon level at any time at depth $\mathrm{x}, \mathrm{A}$ and $\mathrm{B}$ are constant. This equation described only the increase with $\mathrm{x}$..

The constant $\mathrm{B}$ is related to the diffusion length LD of the radon gas according to Kristiansson and Malmqvist (1982 and 1984) as:

$$
B=r_{D}
$$

\section{RESULTS AND DISCUSSION}

\section{Radioelement Concentration Measurements}

Table (2) shows the concentration of natural radionuclides as measured by the gamma spectrometric techniques. As well as the specific activities obtained by the conversion factors stated in Table 1

\section{The obtained results show that for the radioelement's concentrations}

$\mathrm{Ra}$ (ppm), it ranges from 2 to 114 with an average of 14.57., $\mathrm{U}(\mathrm{ppm})$ ranges from 1 to 89 with an average of $11.19 ., \mathrm{Th}(\mathrm{ppm})$ ranges from 1 to 21 with an average of 7.66 while for ${ }^{40} \mathrm{~K}$ it range from 0.02 to 3.19 with an average of 1.02. in general, the obtained data are very greater than the normal value of the crustal abundance of these elements quoted in the literature in range of 2-3 ppm U, 8-12 ppm Th and $2-2.5 \mathrm{~K} \%$.

For the specific activities values in $\mathrm{Bq} / \mathrm{kg}$ : The average activity concentration of ${ }^{226} \mathrm{Ra}(\mathrm{Bq} / \mathrm{kg})$ ranged from 24.7 to 1407.9 with an average 179.95, which is larger than the world activity concentration $(40 \mathrm{~Bq} / \mathrm{kg})$ and the world range of (15-50 Bq/ $\mathrm{kg})$.

Uranium $(\mathrm{eU})(\mathrm{Bq} / \mathrm{kg})$ ranged from 12.35 to 1099.15 with an average 138.20 , which is larger than the world average value $(50 \mathrm{~Bq} /$ $\mathrm{kg})$, UNSCEAR, (1988, 1993, 2000).

The activity for ${ }^{232} \mathrm{Th}(\mathrm{Bq} / \mathrm{kg})$ ranged from 4.06 to 85.26 with an average 31.12, this value is less than the world average value (40 Bq/kg) and world ranges of $(7-50 \mathrm{~Bq} / \mathrm{kg})$, UNSCEAR, (1988, 1993, 2000).

Finally the obtained results for ${ }^{40} \mathrm{~K}(\mathrm{~Bq} /$ $\mathrm{kg}$ ) ranged from 6.26 to 998.47 with an average 320.45 , the measured average values is 
SAYED F. HASSAN et al.

Table 2: The concentration of natural radionuclides as measured by the gamma spectrometric techniques

\begin{tabular}{|c|c|c|c|c|c|c|c|c|}
\hline $\begin{array}{l}\text { Sample } \\
\text { No. }\end{array}$ & $\begin{array}{r}\text { Ra } \\
(\mathbf{p p m})\end{array}$ & $\begin{array}{r}\mathbf{U} \\
\text { (ppm) }\end{array}$ & $\begin{array}{r}\text { Th } \\
\text { (ppm) }\end{array}$ & $\mathbf{k} \%$ & $\begin{array}{r}\text { eU(Ra) } \\
* 12.35 \\
(\text { Bq/kg) } \\
\end{array}$ & $\begin{array}{r}U^{* 12.35} \\
(\mathrm{~Bq} / \mathbf{k g})\end{array}$ & $\begin{array}{r}\text { Th*4.06 } \\
(\mathrm{Bq} / \mathrm{kg})\end{array}$ & $\begin{array}{r}\mathbf{k}^{* 313} \\
(\mathrm{~Bq} / \mathrm{kg})\end{array}$ \\
\hline 1 & 3 & 2 & 2 & 0.88 & 37.05 & 24.7 & 8.12 & 275.44 \\
\hline 2 & 2 & 3 & 4 & 1.12 & 24.7 & 37.05 & 16.24 & 350.56 \\
\hline 3 & 3 & 3 & 4 & 0.97 & 37.05 & 37.05 & 16.24 & 303.61 \\
\hline 4 & 2 & $\mathbf{1}$ & 4 & 0.91 & 24.7 & 12.35 & 16.24 & 284.83 \\
\hline 5 & 4 & 1 & 4 & 0.43 & 49.4 & 12.35 & 16.24 & 134.59 \\
\hline 6 & 7 & 12 & 15 & 0.35 & 86.45 & 148.2 & 60.9 & 109.55 \\
\hline 7 & 2 & $\mathbf{1}$ & 5 & 1.42 & 24.7 & 12.35 & 20.3 & 444.46 \\
\hline 8 & 3 & 3 & 4 & 1.05 & 37.05 & 37.05 & 16.24 & 328.65 \\
\hline 9 & 114 & 89 & $\mathbf{1}$ & 0.56 & 1407.9 & 1099.15 & 4.06 & 175.28 \\
\hline 10 & 4 & 2 & 4 & 0.16 & 49.4 & 24.7 & 16.24 & 50.08 \\
\hline 11 & 5 & 9 & $\mathbf{1}$ & 0.28 & 61.75 & 111.15 & 4.06 & 87.64 \\
\hline 12 & 17 & 10 & 11 & 1.15 & 209.95 & 123.5 & 44.66 & 359.95 \\
\hline 13 & 2 & $\mathbf{1}$ & $\mathbf{1}$ & 1 & 24.7 & 12.35 & 4.06 & 313 \\
\hline 14 & 2 & $\mathbf{1}$ & $\mathbf{1}$ & 0.02 & 24.7 & 12.35 & 4.06 & 6.26 \\
\hline 15 & 18 & 13 & 18 & 0.8 & 222.3 & 160.55 & 73.08 & 250.4 \\
\hline 16 & 28 & 14 & 14 & 1.33 & 345.8 & 172.9 & 56.84 & 416.29 \\
\hline 17 & 24 & 15 & 8 & 1.01 & 296.4 & 185.25 & 32.48 & 316.13 \\
\hline 18 & 7 & 2 & 21 & 1.91 & 86.45 & 24.7 & 85.26 & $\mathbf{5 9 7 . 8 3}$ \\
\hline 19 & 18 & 11 & 11 & 1.19 & 222.3 & 135.85 & 44.66 & 372.47 \\
\hline 20 & 14 & 39 & 15 & 1.77 & 172.9 & 481.65 & 60.9 & 554.01 \\
\hline 21 & 27 & 3 & 13 & 3.19 & 333.45 & 37.05 & 52.78 & 998.47 \\
\hline average & 14.57 & 11.19 & 7.66 & 1.02 & 179.95 & 138.20 & 31.12 & 320.45 \\
\hline
\end{tabular}

small compared with the world permissible value for the ${ }^{40} \mathrm{~K}$ which is $(500 \mathrm{~Bq} / \mathrm{kg})$ and the world range (100-700 Bq/kg), UNSCEAR, (1988, 1993, 2000)

\section{Radiation Hazard Indices Factors for the Selected Station}

Table (3) shows the calculated values of Exposure rate $(\mu \mathrm{R} / \mathrm{h})$, Dose rate $(\mathrm{nG} / \mathrm{h})$, Effective dose rate $(\mathrm{mSv} / \mathrm{y})$, Radium equivalent activity (Raeq)(Bq/kg), External hazard(Bq/ $\mathrm{Kg})$, Internal hazard $(\mathrm{Bq} / \mathrm{Kg})$ and level index I-gamma $(\mathrm{Bq} / \mathrm{Kg})$ respectively as measured by the gamma spectrometric techniques, Using equations (1-7) and the data obtained in Tables $1 \& 2$.

From the table we can get that: The values of exposure rate $(\mu \mathrm{R} / \mathrm{h})$ ranges from 0.28 $\mu \mathrm{R} / \mathrm{h}$ to $58.95 \mu \mathrm{R} / \mathrm{h}$ with an average of 10.83 $\mu \mathrm{R} / \mathrm{h}$ and that average is smaller than the world exposure rate. Since the world exposure rate was $50 \mu \mathrm{R} / \mathrm{h}$ (Beck , 1972). For the exposure dose rate it ranges from $2.70 \mathrm{n} \mathrm{Gy} / \mathrm{h}$ to 479.88 $\mathrm{n} \mathrm{Gy} / \mathrm{h}$ with an average of $91.83 \mathrm{n} \mathrm{Gy} / \mathrm{h}$, since the world exposure dose rate was $70 \mathrm{n} \mathrm{Gy} / \mathrm{h}$ (Beck , 1972), the average dose rate is larger than the world average dose rate. The effective dose rate ranged from $0.01 \mathrm{mSv} / \mathrm{y}$ to $2.35 \mathrm{mSv} / \mathrm{y}$ with an average of $0.44 \mu \mathrm{Sv} / \mathrm{y}$. Since the world effective dose rate was 0.5 $\mathrm{mSv} / \mathrm{y}$, the average effective dose rate is smaller than the world effective dose rate.

The average values of Raeq were 247.72 $\mathrm{Bq} / \mathrm{kg}$, is much less than the recommended maximum value $370 \mathrm{~Bq} / \mathrm{kg}$ (Beretka I.,and Mathaw ,1985). The internal hazard ranged from $0.08 \mathrm{~Bq} / \mathrm{kg}$ to $3.84 \mathrm{~Bq} / \mathrm{kg}$ with an average of $0.66 \mathrm{~Bq} / \mathrm{kg}$. Since the world external hazard was unity (1), (Krieger, 1981), we find that the average internal hazard is smaller than the world internal hazard.

The internal hazard ranges from 0.14 to 7.64 with an average of 1.15. Since the world internal hazard was unity (1), (Krieger, 1981), then the average internal hazard is larger than the world internal hazard. Finally for the lev- 
Table 3: hazard indices factor of the studied samples

\begin{tabular}{|c|c|c|c|c|c|c|c|}
\hline S. No. & $\mathbf{R} \mathbf{a}_{\mathbf{e q}}$ & $\begin{array}{r}\text { Dose } \\
\text { rate } \\
(\mathbf{n G y / h )}\end{array}$ & $\begin{array}{r}\text { Exposure } \\
\text { rate } \\
(\mu R / h)\end{array}$ & $\begin{array}{r}\text { Effective } \\
\text { dose } \\
\text { rate } \\
(\boldsymbol{\mu S v} / \mathbf{y})\end{array}$ & $\begin{array}{r}\text { Internal } \\
\text { hazard } \\
\text { Hin }\end{array}$ & $\begin{array}{r}\text { External } \\
\text { hazard } \\
\text { Hex }\end{array}$ & $\begin{array}{r}\text { Radioactive } \\
\text { index }(I-\gamma)\end{array}$ \\
\hline $\mathbf{1}$ & 69.87 & 27.59 & 3.20 & 0.13 & 0.28 & 0.18 & 0.51 \\
\hline 2 & 74.92 & 41.46 & 4.79 & 0.20 & 0.26 & 0.20 & 0.56 \\
\hline 3 & 83.65 & 39.49 & 4.56 & 0.19 & 0.32 & 0.22 & 0.61 \\
\hline 4 & 69.86 & 22.77 & 2.51 & 0.11 & 0.25 & 0.18 & 0.51 \\
\hline 5 & 82.99 & 16.46 & 1.79 & 0.08 & 0.35 & 0.22 & 0.58 \\
\hline 6 & 181.97 & 108.87 & 12.66 & 0.53 & 0.72 & 0.49 & 1.25 \\
\hline 7 & 87.95 & 32.18 & 3.57 & 0.15 & 0.30 & 0.23 & 0.66 \\
\hline 8 & 85.58 & 40.54 & 4.68 & 0.19 & 0.33 & 0.23 & 0.62 \\
\hline 9 & 1421.4 & 479.88 & 58.95 & 2.35 & 7.64 & 3.84 & 9.50 \\
\hline 10 & 76.48 & 23.53 & 2.69 & 0.11 & 0.34 & 0.20 & 0.52 \\
\hline 11 & 74.30 & 54.16 & 6.58 & 0.26 & 0.36 & 0.20 & 0.51 \\
\hline 12 & 301.53 & 97.95 & 11.41 & 0.48 & 1.38 & 0.81 & 2.08 \\
\hline 13 & 30.51 & 2.70 & 0.28 & 0.01 & 0.14 & 0.08 & 0.20 \\
\hline 14 & 30.99 & 8.27 & 0.97 & 0.04 & 0.15 & 0.08 & 0.20 \\
\hline 15 & 346.09 & 128.20 & 14.85 & 0.62 & 1.53 & 0.93 & 2.37 \\
\hline 16 & 459.14 & 129.66 & 15.16 & 0.63 & 2.17 & 1.24 & 3.15 \\
\hline 17 & 367.19 & 114.54 & 13.61 & 0.56 & 1.79 & 0.99 & 2.51 \\
\hline 18 & 254.40 & 92.51 & 10.20 & 0.45 & 0.92 & 0.68 & 1.82 \\
\hline 19 & 314.84 & 103.78 & 12.13 & 0.50 & 1.45 & 0.85 & 2.17 \\
\hline 20 & 302.65 & 270.88 & 32.43 & 1.32 & 1.28 & 0.81 & 2.13 \\
\hline 21 & 485.81 & 93.01 & 10.49 & 0.45 & 2.21 & 1.31 & 3.41 \\
\hline average & 247.72 & 91.83 & 10.83 & 0.44 & 1.15 & 0.66 & 1.70 \\
\hline
\end{tabular}

el index I-gamma, it ranges from 0.20 to 9.50 with an average of 1.70. Since the world level index I-gamma was unity (1), (Beck, 1972), then the average level index I-gamma is larger than the world level index I-gamma.

\section{Radon Exhalation Rate}

The obtained data for the track density concentration measured in $\left(\mathrm{T} \mathrm{cm}^{2} \mathrm{~d}-1\right)$ were presented in Table (4), these data were used to calculate the radon exhalation rates (Bqm$2 \mathrm{~h}-1)$ and radon concentration $\left(\mathrm{Bq} \mathrm{m}^{3}\right)$ using closed-can techniques employing a solid state nuclear track detector and applying equations (8) were also presented. From the table we can get that the track density $\left(T . \mathrm{cm}^{2} \mathrm{~d}^{-1}\right)$ ranged from $162 \pm 39$ station number (14) to $6925 \pm 49$ station number (9) with an average value of $1270 \pm 98$. The results for the radon concentrations shows that it ranges from $733 \pm 177$ to $31235 \pm 219\left(\mathrm{~Bq} \mathrm{~m}^{3}\right)$ with an average value of $5729 \pm 441$, finally the exhalation rates were ranged from 1.487 to $63.36 \mathrm{~Bq} \mathrm{~m}^{-2}$ $\mathrm{h}^{-1}$, with an average $11.62 \mathrm{~Bq} \mathrm{~m}-2 \mathrm{~h}-1$.

From the data it is obvious that there is a wide range for the obtained date between the high and low values which is mainly due to the large spread in the measured U- concentration also as will be shown in Table (4).

The results also indicates that the measured radon activity and exhalation rates are consistent with the measured uranium concentration (ppm) in most samples especially those having a relatively high concentration.

The studied correlations between both uranium and radium concentrations with the measured exhalations rates are shown on Figs $3 \& 4$

From the figures we can get that, there is a positive correlation between radon exhalation rates and both of uranium and radium concentration with correlation factor of 0.87 . and 0.76 respectively

Finally, the correlation between uranium 
Table 4: The track density, radon concentration and radon exhalation rate

\begin{tabular}{|c|c|c|c|}
\hline S. NO. & $\begin{array}{r}\text { Track Density } \\
\left(\mathbf{T} \mathbf{c m}^{-2} \mathbf{d}^{-1}\right)\end{array}$ & $\begin{array}{r}\text { Radon } \\
\text { Concentration. }(\mathbf{B q} \\
\left.\mathbf{m}^{-3}\right) \\
\end{array}$ & $\begin{array}{r}\text { Radon Exhalation } \\
\text { Rate Ex }\left(\mathrm{Bq} \mathrm{m}^{-2} \mathrm{~h}^{-1}\right)\end{array}$ \\
\hline 1 & $266 \pm 33$ & $1202 \pm 147$ & 2.437 \\
\hline 2 & $275 \pm 37$ & $1242 \pm 166$ & 2.520 \\
\hline 3 & $316 \pm 35$ & $1424 \pm 159$ & 2.889 \\
\hline 4 & $200 \pm 34$ & $900 \pm 153$ & 1.825 \\
\hline 5 & $468 \pm 42$ & $2109 \pm 189$ & 4.278 \\
\hline 6 & $637 \pm 80$ & $2872 \pm 360$ & 5.825 \\
\hline 7 & $299 \pm 45$ & $1349 \pm 205$ & 2.736 \\
\hline 8 & $400 \pm 54$ & $1803 \pm 246$ & 3.658 \\
\hline 9 & $6925 \pm 49$ & $31235 \pm 219$ & 63.360 \\
\hline 10 & $522 \pm 91$ & $2353 \pm 412$ & 4.773 \\
\hline 11 & $627 \pm 104$ & $2829 \pm 471$ & 5.738 \\
\hline 12 & $1422 \pm 107$ & $6413 \pm 481$ & 13.009 \\
\hline 13 & $183 \pm 23$ & $824 \pm 103$ & 1.672 \\
\hline 14 & $163 \pm 40$ & $733 \pm 177$ & 1.487 \\
\hline 15 & $2157 \pm 698$ & $9727 \pm 3146$ & 19.730 \\
\hline 16 & $1831 \pm 99$ & $8256 \pm 444$ & 16.746 \\
\hline 17 & $3416 \pm 165$ & $15405 \pm 741$ & 31.248 \\
\hline 18 & $1111 \pm 81$ & $5009 \pm 363$ & 10.159 \\
\hline 19 & $1476 \pm 103$ & $6657 \pm 461$ & 13.504 \\
\hline 20 & $3707 \pm 97$ & $16721 \pm 440$ & 33.917 \\
\hline 21 & $276 \pm 38$ & $1246 \pm 170$ & 2.528 \\
\hline average & $1270 \pm 98$ & $5729 \pm 441$ & 11.620 \\
\hline
\end{tabular}

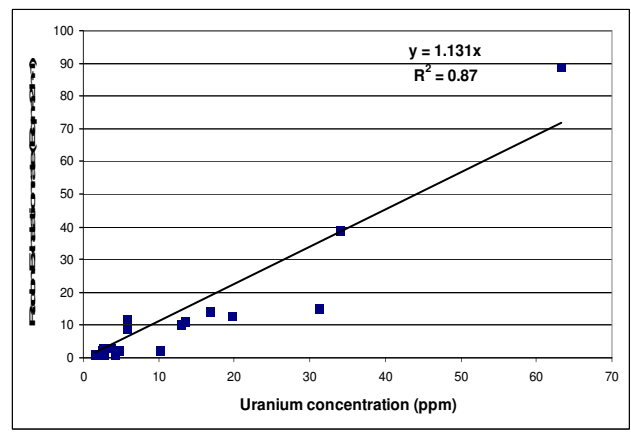

Fig. 3: Correlation between radon exhalation rat and the uranium concentration for the studied sample

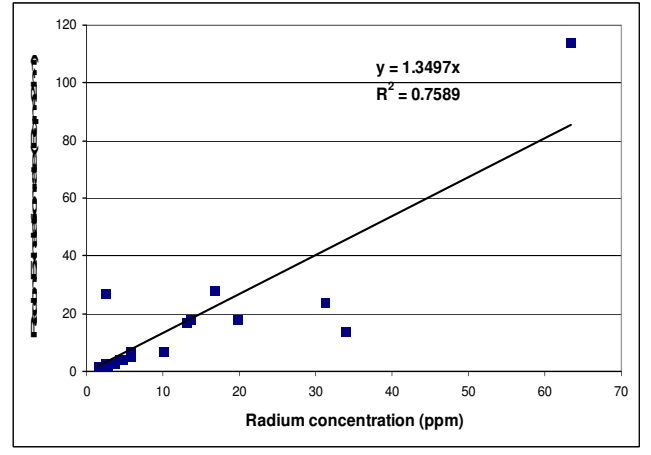

Fig.4: Correlation factor between radon exhalation and equivalent radium concentration for the studied samples 
concentrations and radium equivalent in the studied samples were represented graphically on Fig. (5), a very high value 0.837 for the correlation factor was also observed, indicating a state of secular equilibrium between uranium and radium in the studied samples

\section{Diffusion Coefficients, Diffusion Lengths and Radiation Constants}

The allover numbers of the measured stations were classified into three main zones according to the measured Rn- Gas concentration, Table (5) shows the station numbers that belongs to each zone, while Table (6) shows the lithology of each station.

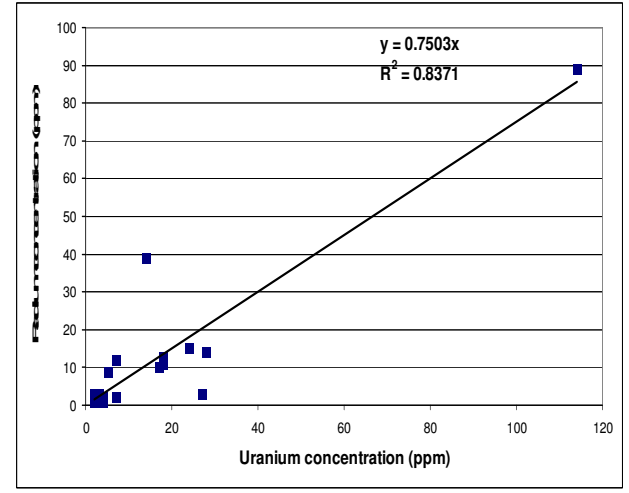

Fig. 5: Correlation between uranium concentration and equivalent radium for the studied samples

Table 5: Classification of the station

\begin{tabular}{lr}
\hline Zone Type & Station number \\
\hline Low level zone & $1,6,7,8,10,11,13,14,19,20$ \\
Medium level zone & $2,3,4,5,12,21$ \\
High level zone & $9,15,16,17,18$ \\
\hline
\end{tabular}

Table 6: Lithology of the measured stations in Wadi Naseib, include locations

\begin{tabular}{|c|c|c|c|c|c|c|c|}
\hline $\begin{array}{l}\text { Station } \\
\text { no }\end{array}$ & & Latitude & & Lon & gitude & Lithology & $\begin{array}{r}\mathbf{U} \\
(\mathbf{p p m})\end{array}$ \\
\hline $\mathbf{1}$ & $29^{\circ}$ & $03 \cdot 56 " \mathrm{~N}$ & $\mathbf{3 3}^{\circ}$ & $23^{\prime}$ & O8"'E & Channel fill-Quaternary deposits & 2 \\
\hline 2 & $29^{\circ}$ & $03,53 " \mathrm{~N}$ & $3^{\circ}{ }^{\circ}$ & 23' & 20"E & Channel fill-Quaternary deposits & 3 \\
\hline 3 & $29^{\circ}$ & $03 \cdot 47 " \mathrm{~N}$ & $33^{\circ}$ & 23' & $24 " E$ & Channel fill-Quaternary deposits & 3 \\
\hline 4 & $29^{\circ}$ & $033^{\prime} 42^{\prime \prime} \mathbf{N}$ & $33^{\circ}$ & 23' & 28 "E & Channel fill-Quaternary deposits & $\mathbf{1}$ \\
\hline 5 & $29^{\circ}$ & $03 \cdot 34 " \mathrm{~N}$ & $3^{\circ}$ & 23' & $24 " \mathbf{E}$ & Channel fill-Quaternary deposits & $\mathbf{1}$ \\
\hline 6 & $29^{\circ}$ & $03^{\prime} 33^{\prime \prime} \mathbf{N}$ & $33^{\circ}$ & 23 & 23 'E & $\begin{array}{l}\text { Channel fill-Quaternary deposits } \\
\text { Sandstones of Abu Thora in }\end{array}$ & 12 \\
\hline 7 & $29^{\circ}$ & $03{ }^{\prime} 37^{\prime \prime} \mathbf{N}$ & $3^{\circ}$ & 23 & $32 ' E$ & $\begin{array}{r}\text { down-thown of } W . \text { Naseib major } \\
\text { fault }\end{array}$ & $\mathbf{1}$ \\
\hline 8 & $29^{\circ}$ & 03' $33^{\prime \prime} \mathbf{N}$ & $33^{\circ}$ & 23' & 33 'E & $\begin{array}{r}\text { Sandstones of Abu Thora in } \\
\text { down-thown of } W \text {. Naseib major } \\
\text { fault }\end{array}$ & 3 \\
\hline 9 & $29^{\circ}$ & 03 '34" N & $\mathbf{3 3}^{\circ}$ & 23' & $54 " E$ & $\begin{array}{r}\text { Kaolinite and gibbsite bearing } \\
\text { shale }\end{array}$ & 89 \\
\hline 10 & $29^{\circ}$ & $02 ' 21 "$ N & $\mathbf{3 3}^{\circ}$ & 23' & $57 \cdot E$ & $\begin{array}{r}\text { Kaolinite and gibbsite bearing } \\
\text { shale }\end{array}$ & 2 \\
\hline 11 & $29^{\circ}$ & $022^{\prime} 13 " \mathrm{~N}$ & $33^{\circ}$ & 23' & $53 " E$ & $\begin{array}{r}\text { Kaolinite and gibbsite bearing } \\
\text { shale }\end{array}$ & 9 \\
\hline 12 & $29^{\circ}$ & $02 ' 06 " N$ & $\mathbf{3 3}^{\circ}$ & 23' & $42 " E$ & Middle marl of Um Bogma Fm. & 10 \\
\hline 13 & $29^{\circ}$ & $01 ' 57^{\prime \prime} \mathbf{N}$ & $\mathbf{3 3}^{\circ}$ & 23' & 33"E & Aeolian sand over Abu Thora Fm. & $\mathbf{1}$ \\
\hline 14 & $29^{\circ}$ & $01 ' 57 " \mathrm{~N}$ & $33^{\circ}$ & 23' & 28 "E & Aeolian sand over Abu Thora Fm. & $\mathbf{1}$ \\
\hline 15 & $29^{\circ}$ & $02,03 " \mathbf{N}$ & $3^{\circ}$ & 02' & $27 " \mathbf{E}$ & Gibbsite bearing shale & 13 \\
\hline 16 & $29^{\circ}$ & $02,06 " \mathrm{~N}$ & $3^{\circ}$ & $\mathbf{0 2}$ & 33"E & Gibbsite bearing shale & 14 \\
\hline 17 & $29^{\circ}$ & $01 ' 44^{\prime \prime} \mathbf{N}$ & $3^{\circ}$ & $\mathbf{2 4}$ & O8" E & Gibbsite bearing marl & 15 \\
\hline 18 & $29^{\circ}$ & $01 ' 24 " N$ & $\mathbf{3 3}^{\circ}$ & 24' & $12 " \mathbf{E}$ & Marly dolostone of Um Bogma & 2 \\
\hline 19 & $29^{\circ}$ & 01' 19" N & $33^{\circ}$ & 24' & $12 " \mathbf{E}$ & $\begin{array}{r}\text { Fractured Marly dolostone in G. } \\
\text { El Allouga }\end{array}$ & 11 \\
\hline 20 & $29^{\circ}$ & $01 ' 20 " N$ & $\mathbf{3 3}^{\circ}$ & 24' & $\mathbf{0 8} " \mathbf{E}$ & Black and varicoloured shale & 39 \\
\hline 21 & $29^{\circ}$ & 01' $30 " \mathrm{~N}$ & $33^{\circ}$ & 24' & 11"E & $\begin{array}{r}\text { Kaolinite and gibbsite in base of } \\
\text { Abu Thora Fm. }\end{array}$ & 3 \\
\hline
\end{tabular}


By applying equation (14) we can determine the value of diffusion coefficient (D) and the diffusion length through the soil in our experiment by take $\mathrm{x} 1=25 \mathrm{~cm}$ and $\mathrm{x} 2=75$ or $\mathrm{X} 1=50$ and $\mathrm{x} 2=100$ and take the values of each one of them like N1 and N2 for both season summer and winter and take the average.

Average Radon Concentration Ratio at Different Depths, Diffusion Length, Diffusion Coefficients, Values of the Constants $A$ and $B$ for the Three Zones (Low, Medium and High) in Summer and Winter Times

In the following the above results were discussed as follows:

\section{For the low level zone in summer and winter}

Tables (7-9) show the obtained results for ratio between average radon concentration, values of diffusion constant and diffusion length as well as values of the constan A and $\mathrm{BA}$ and $\mathrm{B}$ respectively. from these tables we can conclud e that:

The value of radon diffusion coefficient for soil in summer was ranged from $1.960 \times$ $10^{-6} \mathrm{~m}^{2} \mathrm{~s}^{-1}$ to $2.018 \times 10^{-6} \mathrm{~m}^{2} \mathrm{~s}^{-1}$ and for winter ranged from $1.899 \times 10^{-6} \mathrm{~m}^{2} \mathrm{~s}^{-1}$ to $1.923 \times 10^{-6}$ $\mathrm{m}^{2} \mathrm{~s}^{-1}$ with an average $(1.950 \pm 0.05) \times 10^{-6} \mathrm{~m}^{2}$ $\mathrm{s}^{-}$, where is the diffusion length in summer was ranged from $1.458 \mathrm{~m}$ to $1.479 \mathrm{~m}$ and for winter ranged from $1.435 \mathrm{~m}$ to $1.444 \mathrm{~m}$ with an average $1.454 \pm 1.928 \mathrm{~m}$.

The constant (B) range from 0.676 to 0.685 with an average 0.681 in summer and for winter range from 0.692 to 0.696 with an average 0.694 while the constant $\mathrm{A}\left(\mathrm{K} \mathrm{Bq} / \mathrm{m}^{3}\right)$ ranged from 4.14 to 5.15 with an average 4.65 in summer, and for winter range from 2.75 to 3.17 with an average 2.96 .

The data in for ratios between average radon concentration in summer and winter at different depths were represented graphically on Fig (6), indicating a higher values for sum-
Table 7: Ratio between average radon concentration in summer and winter at different depths in the low level zone

\begin{tabular}{lrrr}
\hline $\begin{array}{l}\text { Radon } \\
\text { concentration }\end{array}$ & $\begin{array}{r}\text { In summer } \\
(\mathrm{S})\end{array}$ & $\begin{array}{r}\text { In winter } \\
\text { (W) }\end{array}$ & $\begin{array}{r}\text { Ratio } \\
\text { (K Bq/W } 3 \text { ) at }\end{array}$ \\
different depths & & & \\
\hline At $25 \mathrm{~cm}$ & $1.035 \pm 0.098$ & $0.628 \pm 0.116$ & 1.64 \\
At $50 \mathrm{~cm}$ & $1.318 \pm 0.126$ & $0.784 \pm 0.121$ & 1.68 \\
At $75 \mathrm{~cm}$ & $1.451 \pm 0.129$ & $0.972 \pm 0.163$ & 1.49 \\
At $100 \mathrm{~cm}$ & $1.857 \pm 0.160$ & $1.421 \pm 0.180$ & 1.30 \\
\hline
\end{tabular}

Table 8: The values of diffusion constant and diffusion length of radon for Soil, compressed at low level zone of radioactivity (summer and winter)

\begin{tabular}{|c|c|c|c|c|}
\hline Diffusion medium zone & $\begin{array}{r}\text { Diffusio } \\
\mathrm{X}\end{array}$ & $\begin{array}{l}\text { nstant } \\
\left.\mathrm{m}^{2} \mathrm{~s}^{-1}\right)\end{array}$ & Diffusion & th (m) \\
\hline Low level zone (summer) & Max. & 2.018 & Max. & 1.479 \\
\hline & Min. & 1.960 & Min. & 1.458 \\
\hline Low level zone (winter) & Max. & 1.923 & Max. & 1.444 \\
\hline & Min. & 1.899 & Min. & 1.435 \\
\hline Average & & $0 \pm 0.05$ & & \pm 1.928 \\
\hline
\end{tabular}

Table 9: Values of the constants A and B in the Equation (11), for the station of low level zone of radioactivity (summer and winter)

\begin{tabular}{|c|c|c|c|c|}
\hline \multirow{2}{*}{$\begin{array}{l}\text { Constant } \\
\text { B }\end{array}$} & \multicolumn{2}{|c|}{ Summer (August) } & \multicolumn{2}{|c|}{ Winter (February) } \\
\hline & & 0.676 & & 0.692 \\
\hline & & 0.685 & & 0.696 \\
\hline & With average: & 0.681 & With average: & 0.694 \\
\hline \multirow[t]{3}{*}{$\mathrm{A}(\mathrm{K} \mathrm{Bq} / \mathrm{m} 3)$} & & 5.15 & & 3.17 \\
\hline & & 4.14 & & 2.75 \\
\hline & With average: & 4.65 & With average & 2.96 \\
\hline
\end{tabular}

mer time compared with winter time for all depths

For medium level zone in summer and winter

Tables (10-12) show the obtained results for ratio between average radon concentration, 


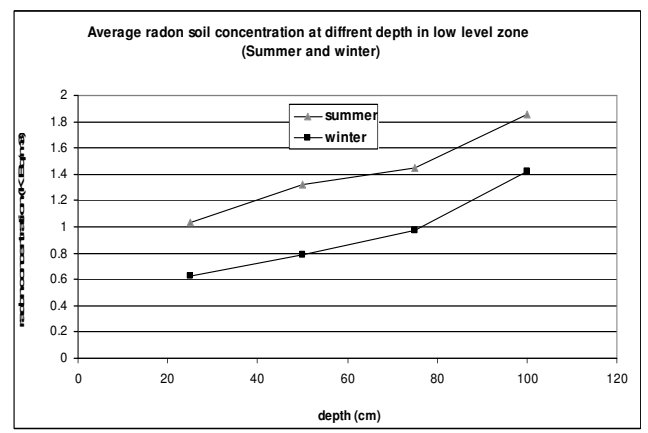

Fig.6: Average radon soil concentration at different depth in low level zone (summer and winter)

Table 10: Ratio between radon concentration in summer and winter at different depths in the medium level zone

\begin{tabular}{lrrr}
\hline $\begin{array}{l}\text { Radon concentration } \\
(\mathrm{K} \mathrm{Bq} / \mathrm{m} 3) \text { at different }\end{array}$ & $\begin{array}{r}\text { In summer } \\
(\mathrm{S})\end{array}$ & $\begin{array}{r}\text { In winter } \\
(\mathrm{W})\end{array}$ & $\begin{array}{r}\text { Ratio } \\
\mathrm{S} / \mathrm{W}\end{array}$ \\
depths & & & \\
\hline At $25 \mathrm{~cm}$ & $1.742 \pm 0.168$ & $1.108 \pm 0.153$ & 1.572 \\
At $50 \mathrm{~cm}$ & $2.546 \pm 0.254$ & $1.957 \pm 0.477$ & 1.300 \\
At $75 \mathrm{~cm}$ & $3.053 \pm 0.265$ & $2.503 \pm 0.263$ & 1.219 \\
At $100 \mathrm{~cm}$ & $4.347 \pm 0.359$ & $2.996 \pm 0.202$ & 1.450 \\
\hline
\end{tabular}

Table 11: The values of diffusion constant and diffusion length of radon for Soil, compressed at medium level zone of radioactivity (summer and winter)

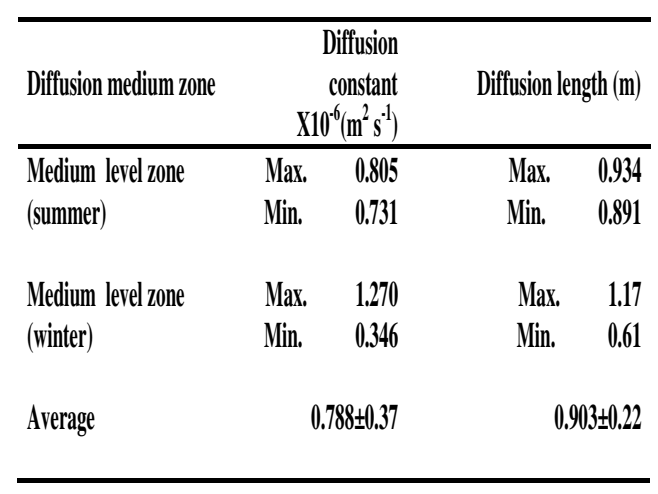

Table 12: Values of the constants A and B in the Equation (1), for the station of medium level zone of radioactivity (summer and winter)

\begin{tabular}{|c|c|c|c|c|}
\hline \multirow{2}{*}{$\begin{array}{l}\text { constant } \\
\text { B }\end{array}$} & \multicolumn{2}{|c|}{ Summer (August) } & \multicolumn{2}{|c|}{ Winter (February) } \\
\hline & & 1.070 & & 0.85 \\
\hline & & 1.12 & & 1.64 \\
\hline & With average: & 1.09 & With average: & 1.24 \\
\hline \multirow[t]{3}{*}{$\mathrm{A}(\mathrm{K} B \mathrm{q} / \mathrm{m} 3)$} & & 6.47 & & 5.52 \\
\hline & & 6.18 & & 3.60 \\
\hline & With average: & 6.33 & With average: & 4.56 \\
\hline
\end{tabular}

values of diffusion constant and diffusion length as well as values of the constants A and $\mathrm{B}$ respectively. from these tables we can conclude that:

The value of radon diffusion coefficient for soil in summer was ranged from $0.731 \times$ $10^{-6} \mathrm{~m}^{2} \mathrm{~s}^{-1}$ to $0.805 \times 10^{-6} \mathrm{~m}^{2} \mathrm{~s}^{-1}$ and for winter ranged from $0.346 \times 10^{-6} \mathrm{~m}^{2} \mathrm{~s}^{-1}$ to $1.270 \times 10^{-6}$ $\mathrm{m}^{2} \mathrm{~s}^{-1}$ with an average $(0.788 \pm 0.37) \times 10^{-6} \mathrm{~m}^{2}$ $\mathrm{s}^{-}$, whereas the diffusion length in summer was ranged from $0.891 \mathrm{~m}$ to $0.934 \mathrm{~m}$ and for winter ranged from $0.61 \mathrm{~m}$ to $1.17 \mathrm{~m}$ with an average $0.903 \pm 0.22 \mathrm{~m}$.

The constant (B) ranged from 1.07 to 1.12 with an average 1.09 in summer and for winter in ranges from 0.85 to 1.64 with an average 1.24 while the constant $\mathrm{A}\left(\mathrm{K} \mathrm{Bq} / \mathrm{m}^{3}\right)$ ranged from 6.18 to 6.47 with an average 6.33 in summer, and for winter it ranges from 3.60 to 5.52 with an average 4.56 .

The data in for ratios between average radon concentration in summer and winter at different depths were represented graphically on Fig (7), indicating a higher values for summer time compared with winter time for all depths as stated above but with slightly higher values than those recorded for low level zone

\section{For high level zone in summer and winter}

Tables (13-15) show the obtained results for ratio between average radon concentra- 


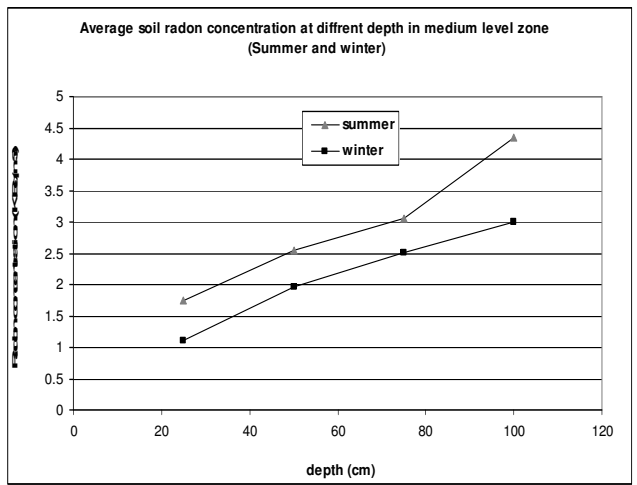

Fig.7: average radon soil concentration at different depth in medium level zone (summer and winter)

Table 13: Ratio between radon concentration in summer and winter at different depths in the high level zone

\begin{tabular}{|c|c|c|c|}
\hline $\begin{array}{l}\text { Radon } \\
\text { concentration } \\
(\mathrm{KB} \text { Bqm3 }) \text { at } \\
\text { different depths }\end{array}$ & $\begin{array}{r}\text { In summer } \\
(\mathrm{S})\end{array}$ & $\begin{array}{l}\text { In winter } \\
\text { (W) }\end{array}$ & $\begin{array}{l}\text { Ratio } \\
S / W\end{array}$ \\
\hline $\mathrm{At} 25 \mathrm{~cm}$ & $10.370 \pm 0.402$ & $7,224+0.228$ & 1.435 \\
\hline $\mathrm{At} 5 \mathrm{50 \textrm {cm }}$ & $14.228 \pm 0 ., 348$ & $8.570 \pm 0.151$ & 1.660 \\
\hline $\mathrm{At} 7 \mathrm{sm}$ & $16.500 \pm 0.297$ & $10.378 \pm 0.202$ & 1.598 \\
\hline $\mathrm{At} 100 \mathrm{~cm}$ & $21.361 \pm 0.410$ & $13.088 \pm \pm .369$ & 1.632 \\
\hline
\end{tabular}

Table 14: The values of diffusion constant and diffusion length of radon for Soil, compressed at high level zone of radioactivity (summer and winter)

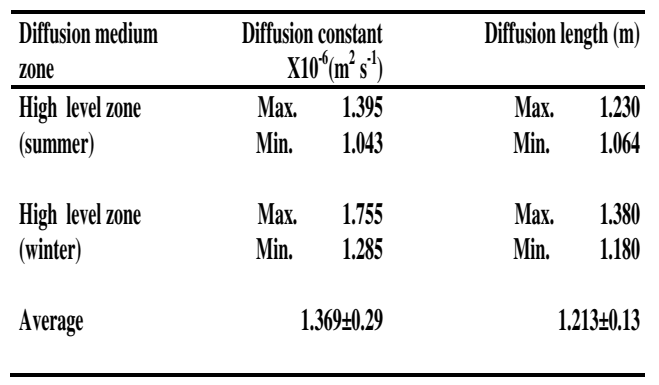

Table 15: Values of the constants A and B in the Equation (1), for the station of high level zone of radioactivity (summer and winter)

\begin{tabular}{|c|c|c|c|c|}
\hline \multirow{3}{*}{$\frac{\text { Constant }}{\text { B }}$} & \multicolumn{2}{|c|}{ Summer (August) } & \multicolumn{2}{|c|}{ Winter (February) } \\
\hline & & 0.81 & & 0.72 \\
\hline & & 0.93 & & 0.84 \\
\hline & With average: & 0.87 & With average: & 0.78 \\
\hline \multirow[t]{3}{*}{$\mathrm{A}(\mathrm{KBq} / \mathrm{m} 3)$} & & 46.361 & & 34.17 \\
\hline & & 36.50 & & 23.85 \\
\hline & With average: & 41.431 & With average: & 29.01 \\
\hline
\end{tabular}

tion, values of diffusion constant and diffusion length as well as values of the constants $\mathrm{A}$ and $\mathrm{B}$ respectively from these tables we can conclude that:

The value of radon diffusion coefficient for soil in summer was ranged from $1.043 \times$ $10^{-6} \mathrm{~m}^{2} \mathrm{~s}^{-1}$ to $1.395 \times 10^{-6} \mathrm{~m}^{2} \mathrm{~s}^{-1}$ and for winter ranged from $1.285 \times 10^{-6} \mathrm{~m}^{2} \mathrm{~s}^{-1}$ to $1.755 \times 10^{-6}$ $\mathrm{m}^{2} \mathrm{~s}^{-1}$ with an average $(1.369 \pm 0.29) \times 10^{-6} \mathrm{~m}^{2}$ $\mathrm{s}^{-}$, whereas the diffusion length in summer was ranged from $1.064 \mathrm{~m}$ to $1.230 \mathrm{~m}$ and for winter ranged from $1.180 \mathrm{~m}$ to $1.380 \mathrm{~m}$ with an average $1.213 \pm 0.13 \mathrm{~m}$.

The constant (B) ranged from 0.81 to 0.93 with an average of 0.87 in summer and for winter in ranged from 0.72 to 0.84 with an average 0.78 while the constant $\mathrm{A}\left(\mathrm{K} \mathrm{Bq} / \mathrm{m}^{3}\right)$ ranged from 36.50 to 46.36 with an average 41.43 in summer, and for winter range from 23.85 to 34.17 with an average 29.01

The data in for ratios between average radon concentration in summer and winter at different depths were represented graphically on Fig (8), indicating a higher values for summer time compared with winter time for all depths as stated above but with slightly higher values than those recorded for both low level and medium level zones 
Fig.8: Average radon soil concentration at different depth in high level zone (summer and winter).

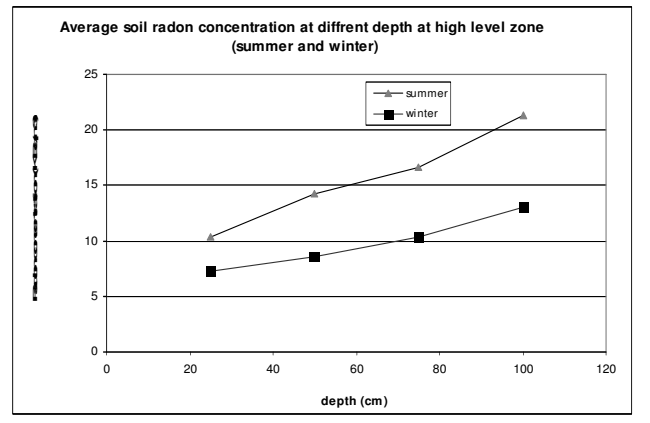

\section{CONCLUSION}

A positive correlation has been found between the radon exhalation rate and the uranium concentration as well as radium concentration of the samples. The activity of the radionuclide's in Wadi Nasib as determined for the selected samples gives rise to effective dose values that is higher than the world's soil average value, especially for public.

The radon concentration increase as depth increase and the radon levels at the depth of 1 $\mathrm{m}$ is nearly twice that level of $0.5 \mathrm{~m}$. This is almost the same result found by Kristiansson and Malmqvist (1982) in sand, which indicates that the sand and geological formation in the studied area may have the same influence on the radon transport at shallow depths.

The value of radon diffusion constant obtained for air (medium of diffusion in the three level zone) (low, medium and high) are agree with Singh (1999) $\left(2.26 * 10^{-6}\left(\mathrm{~m}^{2} \mathrm{~s}^{-1}\right)\right.$.

According to the obtained results, the following recommendation should be undertaken during any exploration processes or other works in area of relatively high radioactive intensity:

(i) The direct contact and handling of the highly radioactive sample and/or ores (if present) as well as their products, should be minimized or eliminated to reduce the time of radiation exposure.

(ii)Use personal protective masks to minimize inhalation of $\alpha$-particles.

(iii)Provide medical surveillance for workers.

(iv)Provide the use of potable dosimeters and their periodical inspection.

(v)Apply shift work when exposed to the hazardous mineralized sediments.

\section{REFERENCES}

Abumurad, K.M.; Atallah, M.; Kullab, M.K., and Ismail, A., 1997. Determination of radon soil concentration levels in the governorate of Irbid. Jordan. Radiat. Meas., 28, 585-588.

Al-Bataina, B., and Abu-Kharma , H ., 2004. Study of radon concentration in soil of Samma Town Jordan.Abhath Al-Yarmouk. Basic Sci. Eng., 13, 177-190

Anastasiou, T.; Tsertosa, H.; Christofides, S., and Christodoulides, G., 2003. J Environ. Radioact., 68,159-169.

Beck, H. L., 1972. The physics of environmental radiation fields. Natural radiation environment II. CONF-720802 p2- Proc. 2nd Inter. Symposium on the Natural radiation Environment

Beretka, I., and Mathaw, P. I., 1985. Natural radioactivity of Australin building materials, industrial wastes and by-products. Health Physics, $48,87-95$

Cherouati, D.E.; Djeffal, S., and Durrani, S.A., 1988. Nucl Tracks Radiat.Meas., 13, 583

El Rakaiby, M. I., and El Aassy, I. E.,1990. Structural interpretation of Paleozoice Mesozoic rocks, southwestern Sinai, Egypt. Ann. Geol. Surv. Egypt, XVI

Gomez Escobar,V.;Vera Tome, F., and Lozano, J.G., 1999 Procedure for the determination of $222 \mathrm{Rn}$ exhalation and effective 226Ra activity in soil. Applide Radiation and Isotopes ,501039-1047. 
Grasety, R.L., and Morgo-Campero, A., 1978. Mapping and integrated radon emanation for detection of long distance migration of gases within the earth; techniques and principles. J. Geophys. Res. , 83, 3593-3549

Hassan, S. F., 2000. Measurements of Radon-Gas Concentration and Radon-Progeny in Uranium Exploration Galleries Allouga, Sinai. Master Degree, Fac. Sci., Cairo Univ.

Recommendation of the International Commission on Radiological Protection Atomic Energy Agency (ICRP), 1979. Technical reports series. No. 45, pergamon press, Oxford

International Atomic Energy Agency (IAEA), 1996. Internal Basic Safety Standards for Protection Against Ionizing Radiation and for the Safety of Radiation Sources. Safety Series No. 115

Khan, A. J.; Prasad, R., and Tyagi, R. K.,1992. Measurement of radon exhalation rate from some building materials. Nucl. Tracks Radiat. Meas., 20, 609-610.

Korany et al., 2013. Depth and Seasonal Variations for the Soil Radon-Gas Concentration Levels at Wadi Naseib Area, Southwestern Sinai, Egypt. J. Phys. Chem. Biophys., 3(4), 123

Krieger, R., 1981.Radioactive of construction materials. Betonwerk Fertigteil Tech.,47, 468

Mohamed Abd-Elzaher., 2012 .An Overview on Studying 222Rn Exhalation Rates using Passive Technique Solid-State Nuclear Track Detectors. Amer. J. Appl. Sci., 9 (10), 1653-1659

Said, A. F.; Abdel-Razek, Y. A., and Hassan, S. F., 2009. Assessment of the Environmental Radioactivity Impacts in the Mill, Tailing and surrounded Area of G-I Uranium Occurrence. report, Nuclear Materials Authority (NMA), Cairo, Egypt.

Schery, S.D.; Holford, D.J.; Wilson, J.L., and Phillips, F.M., 1988. The flow and diffusion of radon isotopes in fractured porous media, Part 1 Finite slabs. Radiat. Prot. Dosi., 24, 185

Tanner,A. B., 1980. Radon migration: A supplementary review. In: the Natural Radiation Environment. Springfield, VA, National Technical Information Service. , 3, 5-56

United National Scientific Committee on the Effects of Atomic Radiation (UNSCESR), 1988. Sources, Effects and Risks of Ionizing Radiation. United Nations Scientific Committee on the Effects of Atomic Radiation, Report to the General Assembly, with annexes. United Nations sales publication. E.88.IX.7. United Nations,

United National Scientific Committee on the Effects of Atomic Radiation (UNSCESR), 1993. Sources and Effects of Ionizing Radiation. United Nations Scientific Committee on the Effects of Atomic RadiationReport to the General Assembly. With scientific annexes. United Nations sales publication E.94.IX.2. United Nations

United National Scientific Committee on the Effects of Atomic Radiation (UNSCEAR), 2000. United Nations Scientific Committee on the Effect of atomic radiation. Sources, .effect and risk of ionizing radiation, United Nations, New York

Wilkening, M., 1990. Radon in the environment, studies in environmental Science (40). Elsevier Science Publishers B.,25. 
معاملات الخطورة الأشعاعية, معدلات انبعاث الرادون و مسافة|أنتشار الرادون لبعض عينات التربة منطقة وادي نصيب, سيناء ,مصر

$$
\text { سيد فهمي حسن ، محمد السيد النجدي ، احمد شطاو قرني احمد قرني }
$$

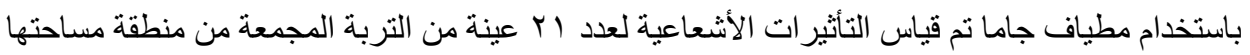

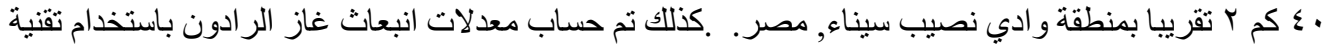

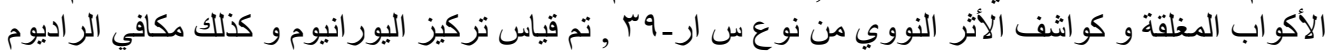
ل الهذه العينات

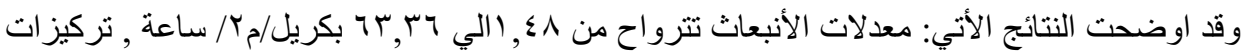

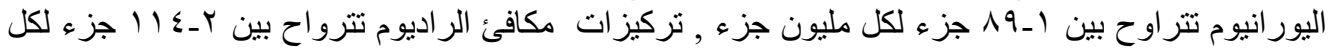

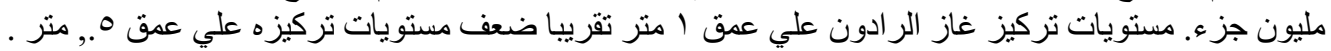

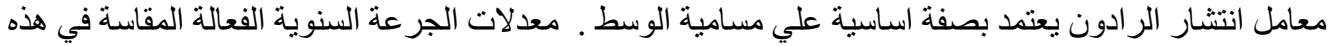

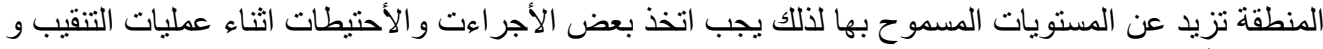

